\title{
FEMINISM AND TRANSLATION
}

Olga Castro and Emek Ergun

\section{INTRODUCTION TO THE FEMINIST POLITICS OF TRANSLATION}

Since the 1990s, we have witnessed a gradual increase in the production of research and scholarship on women, gender, feminism and translation. This growth has led to the topic being incorporated into the curricula of many (largely western) universities, as part of courses on translation theories and methodologies or as independent courses devoted to analysing the interactions between women, gender, feminism and translation. Such increased integration into academic settings has brought upon an unprecedented institutional recognition to the field of Feminist Translation Studies. Yet, it should be noted that there is no consensus in regard to the name of this field, which investigates translation theories and practices developed and carried out from feminist perspectives that are themselves multiple: we prefer the title Feminist Translation Studies for its open-endedness and political emphasis on plurality and power.

In this chapter, we provide an overview of the dynamism of the existing field with its emphasis on translation as a central aspect of feminist politics. We also aim to reconfigure feminist translation as a substantial force and form of social justice activism against intersecting regimes of domination, both locally and transnationally. The chapter does not, therefore, pursue a narrow, fixed understanding of feminism as a form of gender-only politics that belongs exclusively to the west. Rather, we problematise this monolinguistic, oppositional, essentialist and binary approach to feminism, seeking to expand our understanding of feminist action not 
only to include feminist translation as activism against interlocking systems of domination, but also invite the production of more scholarship to rethink feminist translation through theories and practices developed in different geohistorical and inter/disciplinary contexts. We are aware of the fact that, as authors of the chapter, we are both epistemologically, academically and geopolitically situated within the west (not seamlessly though, as we both are also transnationally displaced subjects inhabiting several in-between spaces), which necessarily influênces the ways in which we tell the histories, theories and cases of feminist translation. Thus, we would like to emphasise that, recognising the blind spots that our situatedness brings upon us, we present this chapter as a partial introduction to feminist translation and an invitation to undertake more research on other 'feminist translation' theories and practices.'

We start the chapter by providing a historicat overview of feminist translation, which challenges the conventional 'origin story' of Feminist Translation Studies that presents the Canadian School as the birthplace and universal paradigm of the praxis. We then discuss five key areas of research in the field, which not only reveal the trends in the existing scholarship on feminist translation, but also hint at the remaining gaps in the field. Exploring interdisciplinary links between Feminist Translation Studies and transnational feminism, particularly its notion of 'the politics of location' as it informs the politics of translation, the following section discusses what we call an 'intersectional and transnational turn' in Feminist Translation Studies that further highlights the urgency of building more interdisciplinary bridges between feminist studies and translation studies. We end our chapter discussing the remaining gaps in Feminist Translation Studies with the hope that more researchers, theorists and translators get inspired by the partial story we tell here to make their own stories of feminist translation. 


\section{HISTORICAL TRAJECTORY OF FEMINIST PERSPECTIVES ON TRANSLATION}

'Feminist translation' is often introduced to describe the theories and practices developed in bilingual Quebec, Canada, by a group of translators and translation scholars in the 1970s and 1980s. The Canadians were indeed first in openly claiming the label 'feminist translation' to describe their efforts to incorporate feminist values into their avant-garde literary translation projects and enable new ways of articulation to subvert and unsettle the patriarchal language. Due to such self-claimed epistemic authority, partially enabled by their geopolitics of location, Canadian feminist translation is often presented as the original, universal paradigm of feminist translation. The fact that three of the most influential monographs published on the topic were authored by Canadian scholars also seems to have reinforcéd this perception (see Lotbinière Harwood 1991, Simon 1996 and von Flotow 1997).

Can we challenge the narrative that the Canadian School is the origin of feminist translation and argue that theories and practices of feminist translation had emerged long before and in other geographies, even if they were not self-proclaimed? Indeed, 'feminism' as an intensely contested marker is not always self-declared (particularly when taking into account different locations) and any sociopolitical struggle aimed at challenging and disrupting gender power relations (as well as other relations of power as they intersect with gender) could be tentatively included under that label, irrespective of whether it is self-proclaimed. We could argue that many cases of feminist approaches to translation date back centuries, long before the Canadian school emerged. Reconceived in this way, feminist translation encompasses not only politically engaged textual translation strategies, as proposed by the Canadian school as key tools of feminist translation, but also any form of discursive political intervention made in various processes of translation in pursuit of gender justice - e.g. the strategic use of translation as an 
apparatus of cross-border dialogue to disseminate feminist ideas and build transnational feminist solidarities. Elaborating the history of feminist translation in such a geohistorically expansive context is urgently needed to reveal that the interaction between gender politics and translation politics is not a recent trend.

\subsection{Early Examples of Feminist Interventions in Translation}

The isolated, yet remarkable, early contributions of several women translators who challenged the traditional gendered views of translation by writing their eritical reflections in prefaces, dedications, footnotes or private correspondence are worthy of further attention. Focusing on western contexts, in her preface to the translation of The Mirrour of Princely Deedes and Knighthood, Margaret Tyler reflected in the seventeenth century on how a 'womanly translation of a manly text' required her to challenge the pre-established divisions between literary gender and sex, a preface that Sherry Simon defined as 'a feminist manifesto' (1996: 48). In the same century, Aphra Behn's strategy of ádding a female character (a 'Fair Lady') into her translation of Discovery of Many Worlds by Fontenelle sought to advocate for education for women. Behn explicitly informed her readers about this change, which could also be considered an ethical gesture of feminist disclosure (Ferguson 1985: 149).

Another kind of feminist intervention appeared in Susannah Dobson's and Elizabeth Carter's eighteenth century translations from Greek and Latin, challenging the patriarchal rule of allowing women to translate only texts of secondary literary value written in European vernacular languages (Agorni 2005). Aware of the risk of their translations of esteemed (male) authors being undervalued, many women translators at that time hid their gender. Some of them 
published anonymous translations, while others used male pseudonyms. Therese Huber, for example, signed her translations using her husband's name. Wife and husband being translators, Huber was very aware of the exploitation suffered by women translators and publicly condemned women not getting directly paid and being able to translate only after they had complied with all 'their' domestic duties (Wolf 2005: 20).

One of the most widely studied examples of feminist translation in the nineteenth century is the non-sexist rendering of the Bible. Most of the English translations perpetuated the invisibility and stereotypical representations of women in the source text (Simon 1996: 105). However, Julia E. Smith's 1876 translation and suffragist Lûcy Cady Stanton's 1898 The Woman's Bible reconsidered the Bible 'as a political instrument for the subjugation, but also the liberation, of women from the yoke of traditional male denigration' (cited in von Flotow 2000: 18, see also Shaw 1993). The religious fervour of the time helped those works of translation reach many women and raise critical awareness on sexual discrimination. Indeed, using translation as a tool for disseminating feminist ideas was a key translation strategy of the time: Nísia Floresta Brasileira Augusta, for example, introduced the political writings of Mary Wollstonecraft in Brazil (Dépêche 2002).

More recent examples of feminist interventions in the translation of religious texts include the non-sexist English translations of parts of the Bible from the late 1970s - e.g. Joann Haugerud's partial translation, The Word for Us (1977) and An Inclusive Language Lectionary (1983), where all the sexist or masculinist expressions are replaced by gender-inclusive language. Both of these translations include prefaces, footnotes and epilogues where the translators justify their interventions, arguing that the source text's sexist language was caused 
by the subjective (patriarchal) interpretations of transcribers in ancient times, and thus fail to convey the 'originally inclusive' divine message.

All the examples above highlight the fact that feminist interventions in translation date back centuries and have manifested themselves in diverse forms in response to diverse geohistorical realities. Yet, the Canadian School has been so definitive in the theoretical formulation and institutional recognition of feminist translation that it remains a significant point of reference.

\subsection{Canadian School of Feminist Translation}

The specific cultural and political context of Quebec in the 1970s and 1980s facilitated the English translations of numerous experimental, avant-garde feminist writings by francophone Québécoise 'authers' such as Nicole Brosșard, France Théoret, Madeleine Gagnon, Lise Gauvin, Louky Bersianik and Denise Boucher. These texts were informed by a politics of identity that linked sexual difference (and the alienation of women in the phallocentric language) to cultural difference (the hegemonic status of Anglo values in francophone Quebec). When Canadian feminist translators (e.g. Barbara Godard, Marlene Wildeman, Fiona Strachen, Kathey Mezei, Linda Gaboriau, Susanne de Lotbinière-Harwood, Luise von Flotow and Howard Scott) faced the task of translating these feminist texts, they noticed they needed new ways to rearticulate the source text's consci(enti)ous attacks (e.g. use of puns) on misogynistic linguistic conventions. Their practice emerged from these subversive efforts to resist and disrupt patriarchal forms of language when translating feminist texts from French into English. For instance, due to the

inherently characteristics of French (which linguistically makes gender explicit) and English 
(which does not do so as often), they created new grammatical expressions that did not obscure the sexual and cultural difference of the source text.

Canadian feminist translators conceive of translation as a continuation of the process of creating and disseminating meaning within a contingent network of feminist discourses. In de Lotbinière-Harwood's words, 'as a feminist translator, my choices are informed by the emerging women's culture. ... [and] the feminist translation strategies I'm developing contribute to this emerging women's culture' (1988: 44). As part of these strategies, Canadian feminist translators developed their own terminology to name their interventions, ranging from 're-belle et infidèle' (de Lotbinière-Harwood 1991: 21) -challenging one of the most widespread sexist metaphors about translation (see 3.1. below)- to 'woman-handling' the text (Godard 1990: 91). Those translation strategies were later classified by von Flotow (1991) as supplementing, prefacing and footnoting and hijacking the text, defined respectively as "compensating for the differences between languages' (1991: 75); including metatexts to inform the reader about the 'political motivations of the strategies' (1991: 76) and reclaiming the source text and 'appropriat[ing] it, ma[king] it her own to reflect her political intentions' (1991: 79). In later works, von Flotow offered a new definition of hijacking as 'a process by which a feminist translator applies "corrective measures" to the work in hand, appropriating the text in order to construct feminist meaning' (1997: 82). This has been the most controversial feminist translation strategy, often misunderstood as a real 'hijacking' -completely ignoring that Canadian feminist translators always disclose their interventions to the reader and very often work "closely with the author[s] on the English version' (1991: 79). We could, thus, argue that the term 'hijacking' does not best represent Canadian feminist translators' textual interventions, as they demand for a close 
cooperation between the text, author and translator in a process called 'co-authership' (de Lotbinière-Harwood 1991: 156).

Context has been crucial to the formulation and articulation of Canadian feminist translation strategies (de Lotbinière-Harwood 1991: 125). Yet, the Canadian strategies have often been taken as the universal feminist translation paradigm applicable to any texts being translated under any circumstances, ignoring, for example, that these strategies are of limited use for translations of texts 'hostile' to feminist concerns. For instance, one of the fiercest critics of Canadian feminist translators, Rosemary Arrojo called them 'hypocritical', 'incoherent' and 'opportunistic traitors' who sabotage other people's texts and impose their own political agendas in an 'infamous double standard' (1994: 149) that shows clearly 'contradictory ethics' (1995: 73). Other critics of Canadian feminist translators accused them of 'elitism and cultural inappropriateness, even meaningless' (Gillaumin 1995: 11), stating that their translations were intelligible only for a small number of bilingual scholars able to appreciate the linguistic skills of the authors and translators (Voldeng 1985: 139). Thus, their political use is perceived as limited at best. However, these experimental rewritings were in fact meaningful and deliberate aiming to avoid the patriarchal and Anglophone appropriation of the cultural/sexual difference of the original text written in Francophone Quebec.

Canadian feminist translators have also been accused of being essentialist for their commitment "to the (re)construction of a genuinely distinctive female culture, an aim in line with the proposals of cultural feminism' (Martín Ruano 2005: 35). They seem to have pursued a naïve universalist understanding of women's oppression that overlooked their own position as privileged (western, white, intellectual) women, like the authors they translated. While recognising this positionality of power, we must remember that they belonged to the 
marginalised cultural and political system of Quebec, confronting hegemonic Anglo values through their translations. Thus, their translations celebrate the politically and culturally unique feminist voices and stories of Quebec and avoid domesticating (assimilative) translation strategies while rendering French texts into English. However, it is equally important to acknowledge that the Canadian school of feminist translation still enjoys a geopolitical privilege from which they have had the opportunity to cross-culturally disseminate their translation theories and practices under the label 'feminist translation' - this is clearly illustrated by their inclusion in some of the most prominent anthologies in the discipline (see Bassnett and Lefevere 1990, and Venuti 2000).

\subsection{Feminist Translation Beyond Canada}

Canadian feminists' translation praxis emerged in a specific context in response to specific sociopolitical and literary needs. Other contexts, with their own particular needs, have called for different feminist approaches to translation. In what follows we summarise some of those feminist translation strategies most widely discussed in (western) academic circles.

Feminist translators working with explicitly patriarchal texts in the 1980s faced several dilemmas. Two US-American scholars and translators of Latin American fiction are excellent examples. Suzanne Jill Levine's strategies when translating into English an 'oppressively male, narcissistic, misogynistic and manipulative' (1983: 92) postmodern text by Guillermo Cabrera Infante are revealing: Levine deliberately chooses to become a 'subversive scribe' who subverts the text with the author's permission, even cooperation (Levine 1991). Equally revealing are the women-friendly rewritings of Carol Maier translating the misogynistic work of Cuban poet 
Octavio Armand, which she defines as a 'patriarchal parthenogenesis' (1985: 4) - a birth in which only the father is present. The sexist content of the source text motivated her to produce a women-friendly translation, adding to the English translation a new female character, the mother missing from the original storyline. Rather than silencing Armand's voice, she considered 'essential that as translators women get under the skin of both antagonistic and sympathetic works. They must become independent, "resisting" interpreters' (1985: 4).

In the mid-1990s, Carol Maier, together with her US-American colleague Françoise Massardier-Kenney (1996), proposed a 'woman-identified approach' to the translation of women-authored literary works. Their proposal is framed within a deconstructionist view of feminism, as mainstream feminism would be 'problematic for anyone wanting to interrogate the very category of gender' (Massardier-Kenney 1997:55). Their 'woman-identified' approach makes it possible for translator to identify with women authors, but not necessarily as women (our emphasis). Maier's textual strategies used in the English translation of Spanish authors Rosa Chacel and María Zambrano provide the basis for her 'woman-interrogated approach' (Maier 1996, 1998), where translation helps 'throw woman into question, a continuous interrogation and re-definition of gender identities, ... an endeavour to counter the restrictions of a gender-based identity' (Maier 1998: 102).

Despite having previously rejected the term 'feminism', Massardier-Kenney later advocated for recovering it in her 'redefinition of feminist translation practice' going beyond the Canadian school, which, she argued, offered an essentialist view of difference (1997: 56-57). Instead, she called for a 'translation practice that is militant in its focus on the fact that the speaking/writing subject (whether author or translator) is a woman' (1997: 56). With this aim, she puts forward six strategies to implement a feminist translation agenda: recovery, commentary 
and resistance as author-centred strategies, and commentary, use of parallel text and collaboration as translator-centred strategies. It must be noted that although Massardier-Kenney explicitly claims for a non-essentialist approach to feminist translation, her definition of it could still be deemed essentialist due to her focus on the gender of the author or translator, i.e. necessarily a woman.

Recent studies on the English translations of religious texts like the Qurân reveal other feminist translation strategies, particularly about the textual visibility of the feminine and the use of gender-inclusive language. For instance, in her analysis of the four English Quran translations by women between 1995 and 2007, Rim Hassem (2011) concludes that only two of the translations employ strategies to deal with the 'gender balance' challenge and the patriarchal tone of the sacred text, e.g. 'introducing the letter (f) to ensure feminine visibility in the target text and to compensate for some of the linguistic losses between the gender marked Arabic and the gender unmarked English language' (2011:229).

All of the translation strategies mentioned above are developed based on translations of literary (or religious) texts, which are either overtly feminist or explicitly misogynistic; and in all but one the target language is English. However, the majority of translations in today's market are nonliterary texts, from pragmatic texts to audio-visual and advertisement materials, also including specialised documents in technical, medical, legal or business fields. In response to these limitations, Olga Castro argued for a 'non-sexist translation practice' (2010), which highlights the need for a non-sexist language in translation and encourages the incorporation into the target text of the most common strategies for an inclusive/non-sexist language already existent in that target culture, and more and more often used in the production of 'original' texts in the target language. Non-sexist language strategies applied to translation are therefore flexible 
and dynamic procedures, locally negotiated, as there are no rules that would work across all contexts and translation projects. Factors to be considered include the diversity of gender representations in different languages and texts, as well as the variety of textual conventions and genres. The ultimate aim of this proposal is to implement an ethical translation practice bearing in mind the political and social consequences deriving from a sexist or non-sexist use of language, understood as social practice.

\section{MAIN AREAS OF RESEARCH ON FEMINIST TRANSLATION STUDIES}

In this section we offer an overview of five main topics explored in feminist translation scholarship. Although we present these topics as independent categories for ease of reading, it should be noted that there are no clear boundaries between the sections as the themes overlap.

\subsection{Gender Metaphors in Western Discourses on Translation}

The first line of enquiry linking feminism and translation analyses the ways in which women have been metaphorically represented in theoretical discourses of translation, where metaphors are common descriptive tools. Tracing the historical and ideological constructions of translation in paralleLwith traditional gender constructions, Lori Chamberlain reveals that a great deal of these translation discourses are grounded in misogynistic conceptions about gender roles. One of these metaphors is that of 'Les belles infidèles,' an expression coined by Gilles Ménage in seventeenth century France to state that translations, like women, are necessarily 'unfaithful' if 'beautiful.' Chamberlain discloses and contests many more sexist metaphors articulated in 
translation treaties written by celebrated authors from the seventeenth to the twenty first century, such as Thomas Drant, John Florio or George Steiner. Most of these authors compare women and translation when discussing issues of fidelity (to men and to the source text/author) and origin/originality - the paternity of the text, the penetration or rape of the source text/woman, the betrayal of women/translators and the binary opposition between the productive/active work (performed by men/authors) and the reproductive/passive work (performed by women/translators) are some of the common sexist tropes. These sexualised metaphors help justify the hierarchical relation between the source text and the translation - what is presented as a problem of aesthetics is in fact a matter of politics.

\subsection{Women Translators in History}

A second topic focuses on revealing the history of women translators who fought against patriarchal perceptions of writing as a masculine activity. This prevented many women from entering the literary world as authors. Translation, however, was historically considered one of the few modes of intellectual activity appropriate for women - many women who were not allowed to be authors found in translation a way of claiming their place in the literary world. Also, for centuries, translation theories were mainly articulated by translators in their prefaces, footnotes or private correspondence, where they commented on the political and linguistic implications of their practices. Women translators had therefore a chance to produce theoretical metatexts, sometimes even reflecting on gender as limiting and conditioning their practice, thus becoming pioneers of the feminist translation theory. 
However, there is a common tendency to exclude contributions by women translators and theorists from the historiography as well as the theoretical canon of Translation Studies, where, in line with patriarchal epistemic conventions that deem theory as an exclusively male domain, men's works are recognised as the only kinds of legitimate knowledge (e.g. Lefevere 1992, Delisle 2000). Challenging this trend, significant amount of research has been dedicated to unearthing the trans/formative roles of women translators and theorists, revealing their contribution to the discipline by their prefaces, translation strategies and politically guided selection of works to translate - thus, participating in the intellectual movements of their time and disseminating transgressive ideas. An example is Portraits de traductrices [Portraits of Women Translators] edited by Jean Delisle (2002) in response to the criticism received for his earlier anthology Portraits de traducteurs [Portraits of "Translators], which included male translators only despite the apparent claim of a gender-inclusive scope in its title. Other more recent examples about women translators in Russia and Iran can be found in Sergei Tyulenev (2011) Farzaneh Farahzad (2017) respectively.

\subsection{Women Writers in Translation}

Another common area of research focuses on routes of literary dissemination aiming to track the status of women writers in circuits of translation. These studies reveal that literary values have been traditionally assigned by the norms of patriarchal canons. Thus, we observe an obvious tendency to translate fewer women authors, even when a growing number of women writers are recognised with prestigious awards. This pattern is quantitatively illustrated in bibliographical compilations such as Women Writers in Translation: An Annotated Bibliography 1945-1982 
(Resnick and de Courtivron 1984 - the briefness of its several chapters attests to the pervasive exclusion of women's works from the traffic of translation. The same trend continues into contemporary times, as Michael Orthofer demonstrates: in 2010 less than 20 per cent of the books translated into English and published in the US were by women (quoted in Clockrootbooks.com 2011). Other studies have explored the sexist selection criteria of translation anthologies, or the gender-biased attitudes of publishers in their selection of titles for translation. Debates recently initiated by scholars of postcolonial, lesbian and transnational feminisms (see Section 4) have considerably influenced these studies that bring a more intersectional and nuanced critical reflection on cross-border travels of women's writings. Then, what matters is not simply whether or not women writers get translated, but rather (a) which geopolitical, cultural and linguistic realities are believed to yield legitimate stories and truths worthy of translation, and (b) the political consequences of those literary flows that, more often than not, perpetuate 'West-to-the-Rest narratives' (Costa 2006: 73), enforcing the hegemony of western values. A recent example is Lola Sanchez's (2017) analysis of the titles selected for publication by the Spanish publisher Cátedra in their feminist series Feminismos, revealing that while most of the translated works are from geopolitical contexts with imperial legacies (namely the US, the UK, France, Italy and Germany), feminist voices from other parts of the world, including Spanish-speaking parts, are almost nonexistent in the series.

Exposing the male-centric and western-centric tendencies of publishing industries has served as a wake-up call to use translation more consciously and strategically as a tool to help disseminate the works of silenced women writers and, by so doing, transform literary canons. This agenda has facilitated several translation initiatives focused exclusively on women writers, 
with others aiming to increase women's presence in broad-perspective anthologies focusing on specific time periods, literary cultures or genre.

\subsection{Feminist Texts in Translation}

The understanding that translation is crucial to forging cross-border feminist alliances makes another key research topic about feminism and translation, i.e. the study of how feminist ideas, theories and discourses travel (or not) from one cultural context to another via translation, and the geopolitically situated receptions and political consequences of them. The role of translation in consolidating feminist ideas and movements has attracted cónsiderable scholarly attention -for example, Jayakumari Devika (2008) about Kerala, India; Emek Ergun (2017) about Turkey; and Elena Basilio (2017) about Italy.

In order for feminist dialogues and solidarities to be forged in and through translation, the linguistic rendering of the target text must convey the feminist messages of the source text. This, however, has not always been the case, with many 'phallotranslations' (Henitiuk 1999) erasing or distorting the feminist agendas of source texts. In response to that, a popular line of enquiry has been to analyse the ideological and discursive trajectory of (phallo)translations of key feminist texts, particularly focusing on the consequences of the translation process for the reception of traveling texts. Perhaps the most paradigmatic case in point is the first English translation of Simone de Beauvoir's Le deuxième sexe by Howard Parshley in 1951 (Simons 2001, Moi 2004). This was a patriarchal translation that left out almost fifteen per cent of the first French volume and removed around sixty pages from the second one to omit 'uncomfortable' materials transgressing hetero/patriarchal conventions of gender. As a result of 
this translation, Beauvoir was often considered to be an incoherent and intellectually immature philosopher. Not surprisingly, French-speaking and English-speaking feminists struggled with developing a common view of Beauvoir's ideas.

More recently, this research area has also highlighted the political role of paratexts in influencing the reception of translations in the target system, as Ruth Abou Rached's (2017) shows in her analysis of the feminist paratranslation of Iraqi writer-activists in post-2003 US.

In short, the scholarship examining the cross-border travels of feminist texts in and through translation pursue two purposes: (a) to disclose patriarchal translations (often presented as neutral or objective translations, as if such an unsituated practice of translation is possible) of feminist texts and (b) to celebrate feminist translations and reveal their textual and paratextual strategies to inspire the production of more politically engaged translations and transnational dialogues facilitated by translation. Exploring the Chinese translations of Le deuxième sexe and The Vagina Monologues, Zhongli Yu's work (2015) is an excellent example of both objectives.

\subsection{Linguistic Representations of Gender in Translation}

Another well-established line of enquiry consists of analyses of linguistic representations of women and men (also trans and gender-queer identities more recently) in translated texts, comparing it with the way they were portrayed in the source text to reveal the roles of translators in regard to mediating (and challenging) gender norms. These studies, placed at the crossroads of gender, language and translation (Castro 2013a) and sustained by a close interdisciplinary collaboration with feminist linguistics, identify language as a sociopolitical practice and thus conceive translation as a significant venue to study discursive operations of power. 
A considerable number of comparative studies on linguistic representations of gender in translations has revealed the systematic ways in which patriarchal ideologies pervade the translation process, rendering women textually invisible or confined within stereotypical, normative representations. Unless consciously performed to contest (and undermine) patriarchal norms and values, translations tend to reproduce and perpetuate hegemonic values through sexist linguistic practices (Baxter 2005, Ergun 2013a) - some sexist translations simply reproduce the sexism of the source text; others turn a non-sexist text into a sexist one, e.g. by replacing all the neutral pronouns of the source text with masculine ones, following the 'Male-As-Norm Principle' (Braun 1997: 3); and some others are produced from explicitly feminist texts, as in the case of Le deuxième sexe's first English translation. Therefore, it could be argued that unless translators consciously and critically reflect on their location as situated political agents, they will in all likelihood be translating (unconsciously or not) in accordance with hegemonic (patriarchal, heterosexist, racist) values. In fact, even if they subscribe to feminist ethics and politics, they may not be able to practice those values due to pressure or censorship from other mediators (e.g. publishers or commissioners). The ideological conflict between translator María Reimóndez and publisher Rinoceronte over an 'inclusive rendering' or 'feminist manipulation' of one of Mark Haddon's novels into Galician provides a perfect example (Castro 2013b, Reimóndez 2009).

Going against such trends of hegemonic translation, forms and practices of feminist resistance have also been articulated by Feminist Translation Studies scholars with the claim that interventions in linguistic gender practices help achieve social change. Since language both reflects and constructs reality (including that of gender relations), then, feminist translation has much to contribute to the feminist enterprise of transforming gender norms and relations (see 
Section 2 for a discussion about strategies). The level of intervention that feminist translation practices involve is not necessarily any greater than that of other hegemonic translation practices, which tend to be perceived as 'non-interventionist' and 'objective' precisely because they confirm the (unmarked) status quo rather than questioning its truths. Unlike feminist translation's ethical, celebratory recognition of the translator's visibility, hegemonic translation practices tend to demand the translator's invisibility as a precondition of successful translation, which further perpetuates the illusion of 'objective' translation.

\section{INTERDISCIPLINARY GROWTH IN THE FIELD: AN INTERSECTIONAL AND TRANSNATIONAL TURN?}

Since its establishment as a legitimate area of scholarly research and knowledge production from the 1970s onwards, the field of Feminist Translation Studies has expanded theoretically, epistemologically and methodologically by engaging in cross-disciplinary interactions, particularly with feminist studies, literary studies, linguistics and cultural studies, mostly within the context of the western academia. One of the key areas of growth has been in response to the emergence of the ground-breaking concept of 'intersectionality' in feminist studies. While its theoretical conceptualisation can be traced back to the late 1970s, particularly the Combahee River Collective's acclaimed 1977 manifesto 'A Black Feminist Statement,' intersectionality was first coined by Kimberlé Crenshaw (1989). As an analytical framework of difference, intersectionality has changed the landscape of (western) feminist politics and scholarship by emphasising the simultaneous operations of multiple axes of power and identity and how those interplays create unique conditions of im/possibility for situated subjectivities, discourses and 
actions. Intersectionality has challenged the uni-dimensional, gender-centric formation of western 'hegemonic feminism' (Sandoval 2000: 41-42) by recognising racism, capitalism, colonialism, heteronormativity, ableism and so forth, as similarly pervasive systems of oppression that often join forces with patriarchal norms and structures.

Although it is only recently that we see the term 'intersectionality' being openly claimed in Feminist Translation Studies scholarship (Castro and Ergun 2017, Ergun 2013b, von Flotow 2009), the analytical approach it has brought to the praxis of social justice had already started influencing Feminist Translation Studies even when the term itself was not mobilised - e.g. Gayatri Spivak's foundational 1993 essay 'The Politics of Translation' focused both on postcolonial and gender oppression as these forms of power transpired in and through translation. So far, the impact of intersectionality on Feminist Translation Studies research is seen most clearly in the increased critical attention paid to the intertwined operations of gender with race, sexuality and/or geopolitics (particularly in regard to nationalism, colonialism and orientalism) as these materialise in the practice and theorisation of translation. Key anthologies exploring those intersections include José Santaemilia (2005), Dorothy Ko and Wang Zeng (2007), Luise von Flotow (2011), Christopher Larkosh (2011), Olga Castro and Emek Ergun (2017), B.J. Epstein and Robert Gillett (2017) and Luise von Flotow and Farzaneh Farahzad (2017). While the majority of these works do not claim intersectionality as their analytical framework, they nevertheless pursue research agendas that investigate simultaneous operations of power on multiple fronts of cross-border re/signification that is translation.

In fact, questions such as the following are direct products of intersectionality expanding the analytical scope of Feminist Translation Studies: What multifaceted (intersectional) political agendas of social justice are pursued in (feminist) translation - those of beyond a gender-only 
focus - and how are they textually performed? Which feminist texts and authors are prioritised for translation and which ones are not authorised to cross borders at all? Why/how are the voices of third world women writers distorted in the process of translation (as well as marketing and reception)? How does translation serve transnational feminist dialogues and solidarities? Or, how does translation serve colonial, imperial, militarist, orientalist and corporate motives that are simultaneously gendered (and sexualised) processes? How can we reconceptualisê translation as a queering praxis of resignification against normative regimes of sexuality and gender? How are identity differences between the author and the translator, particularly in regard to gender and sexuality, negotiated and articulated in translation practices? How can we reconsider 'queer' as a western discourse that circulates through the neo/colonial paths of the globe?

These questions, by inviting intersectional approaches to translation, challenge and complicate earlier approaches to feminist translation that almost exclusively focused on gender framed habitually in western-centric, binary and essentialist terms. In other words, a renewed intersectional focus has helped Feminist Translation Studies somewhat grow away from an exclusionary, essentialist focus on gender (defined in relation to an abstract notion of a supposedly universal, singular patriarchy) and become more attuned to geohistorically contingent multiple, interlocking systems of domination and corresponding, coalitional agendas of resistance pursued in feminist translation praxes. Interestingly, as Feminist Translation Studies adopted a more intersectional approach to the study of translation, which is a trans-spatial practice by definition, it has also become more attentive to the political implications of that spatiality, or to 'the politics of location' (Rich 1986, Kaplan 1994, Mohanty 2003) - a term coined by US-American feminist poet and scholar Adrianne Rich and adopted as a key conceptual tool by several transnational feminist scholars. The concept is often recapped in 
Rich's self-reflexive statement, 'a place on a map is also a place in history within which, as a woman, a Jew, a lesbian, a feminist, I am created and trying to create' (1986: 212). By embracing the critical lens of intersectionality as well as the politics of location, Feminist Translation Studies can now recognise more easily that every act of feminist translation also has a place in a map and in history within which the languages being used, the texts being translated, the discourses being de/activated and the agents re/signifying the travelling text (author, translator, reader, publisher, etc.) 'are created and trying to create.'

Another theory that has helped spatialise the study of translation in general and feminist translation in particular is Edward Said's 'travelling theory,' or more accurately the theory of travelling theory, first formulated in his 1983 The World, the Text, and the Critic, and later revised in his 1994 article 'Traveling Theory Reconsidered.' This theory importantly asks what happens to a theory when it moves from one place to another? According to Said's model, theories travel in four stages: (1) the point of 'origin,' 'or what seems like one,' where the theory comes into existence and enters the local discursive field, (2) the distance in time and location across which the theory travels and is meanwhile subjected to various situated pressures as a result of which its prominence is modified, (3) the set of conditions of acceptance and resistance that the transposed theory faces in its new environment, (4) the resultant fully or partially transplanted theory being 'transformed by its new uses, its new position in a new time and place' (1983: 226-7). Said explains his travelling theory through a 'case study' on the borrowings and appropriations of Hungarian Georg Lukács' Marxist theory of reification first by Lucien Goldman in Paris and then by Raymond Williams in Cambridge. Although Said's 1983 essay only emphasises the loss that Lukács' theory suffers from in the transformative travel process, he 
revisited the theory in 1994 to take into account the possibility of travelling ideas being rearticulated and revitalised to achieve subversive effects in their new surroundings.

Despite its lack of analytical attention to intersectional power relations operating during travelling processes and to situated agents enabling those processes (most importantly, translators), the potential of Said's theory lies in his conceptualisation of theory as a geohistorically contingent and politically trans/formative (transgressive or reactionary) form of discursive mobility. It is this potential that makes travelling theory a useful analytical framework for translation scholars aiming to reveal the roles of translators/translations in enabling global flows of texts and discourses (Davis 2007, Ergun 2015, Liu 1995, Min 2014, Möser 2017). An alternative helpful analytical model on global flows is provided by Arjun Appadurai in his Modernity at Large (1996) (see particularly his discussion of "ethnospaces" as contentious translational spaces of cross-border contact) although he does not exclusively focus on textual flows, as Said does.

In short, the 'intersectionality turn' and a renewed focus on 'travelling theory' as a function of cultural globalisation have helped both 'spatialise' and 'transnationalise' the study of feminist translation as an increasing number of transnational feminist scholars have begun to recognise the political significance of 'location' in regulating the 'fate' of travelling discourses and acknowledge the political role of translation and translators as key mediators facilitating border-crossings of bodies and texts. That is, transnational feminist theories have inspired Feminist Translation Studies scholars to reconfigure translation both as an anti-patriarchal project of cross-linguistic meaning making and as a geohistorically situated act of knowledge production and solidarity building against regimes of domination. 
Incorporating intersectionality, 'the politics of location', and transnationalism as analytical frameworks has demanded and enabled more production of interdisciplinary scholarship on feminist translation. In fact, in the last decade or so, particularly with the rise of transnational feminist theories and critical border studies, a significant volume of innovative theory and research has been produced on translation beyond Translation Studies, especially in the larger context of women's and gender studies. Some of these works are Kathy Davis' pioneering study on the translations of Our Bodies, Ourselves (2007); Millie Thayer's ethnographic study exploring the role of translation in the making of transnational feminist activisms in Brazil (2010); Richa Nagar's self/reflexive book on the political, epistemological and ethical challenges and promises of producing translational/transnational feminist scholarship (2014); and finally, an edited volume exploring Latin Amerícan, Caribbean and US-based Latina feminisms and their translations and 'translocal' formations (Alvarez, Costa, Feliu, Hester, Klahn and Thayer 2014).

All those feminist studies emphasise the key role of translation and translators in facilitating transcultural encounters and collaborations among feminist actors and discourses. Yet, they rarely forge explicit interdisciplinary connections with Translation Studies, which would enable them to pay closer attention to the textual and linguistic politics of cross-border flows and formations. This lack of collaboration with between Feminist Studies and Translation Studies, which is probably most visible in citations (or lack thereof), seems partly due to the stillessentialist gender-centric framework of Feminist Translation Studies, which makes it difficult to be incorporated into transnational feminist analyses that firmly reject essentialist categories. Another reason seems to be the marginalised status of Translation Studies in US academia (unlike Europe, where Translation Studies is becoming an established part of university 
curricula). As most prominent transnational feminist scholars have been situated in the US, limited access to or familiarity with critical Translation Studies scholarship (be it marked as feminist or not) means that those same scholars who study border-crossings are theoretically and methodologically not fully equipped to analyse the textual particularities of border-crossings, which always take place in translation. As for outside the US and Europe, whether any interdisciplinary dialogues have taken place between Translation Studies and feminist studies is a question waiting to be explored. Indeed, if such interdisciplinary scholarship produced in nonhegemonic languages is revealed, translated and introduced to Feminist Translation Studies, it could help decolonise the largely western-dominated field.

Then, while figuratively acknowledging the centrality of translation in global processes, transnational feminist studies has not paid much attention to the 'worldliness' of translation that enables interpretive processes of cross-border mobility and connectivity. This scarcity of scholarship on how global discursive flows and formations materialise in specific cross-linguistic contexts makes an important interdisciplinary gap that can only be filled if women's and gender studies scholars collaborate with translation scholars, and most specifically with Feminist Translation Studies scholars. A recent example that illustrates the analytical benefits of such a collaboration is 'Gender Studies and Translation Studies,' an article co-authored by Feminist Translation Studies scholar Luise von Flotow and feminist historian Joan W. Scott (2016). The two scholars join their disciplinary expertise to explore the un/translatability of 'gender', an Anglo-American concept that is too often presented as a universal (an epistemic illusion partly sustained by the global hegemony of English). In doing so, they bring politics of translation to the centre of discussion on the globalisation of feminist discourses (which ones? is a key question here) and demonstrate how methodologies of Translation Studies can help feminist 
scholars reveal local agents' contingent negotiations with travelling discourses, the sum of which we call 'globalisation' or 'transnational formations.' The collective chapter that brings together seven feminist scholars across disciplines (Richa Nagar, Kathy Davis, Judith Butler, Ana Louise Keating, Claudia De Lima Costa, Sonia E. Alvarez and Ayşe Gül Altınay), 'A CrossDisciplinary Roundtable on the Feminist Politics of Translation, included in the recent collection Feminist Translation Studies (Castro and Ergun 2017) is another example that illustrates the rich epistemic potential of interdisciplinary dialogues on feminist translation.

Thus, Translation Studies (and more specifically Feminist Translation Studies) is indispensable to the project of equipping transnational feminisms with the necessary methodological tools to identify the particularities and further possibilities of transnationalities. Such interdisciplinary cooperations would yield crucial insights into the on-site workings of corporate (and often hetero/patriarchal) globalisation, which is both sustained and contested in and through translation, and provide us with key lessons on how to forge acts and movements of resistance. That is, we need to cross disciplinary borders more often if we want to learn more about (and engage in more) cultural/linguistic border-crossings, which is the way to counter operations of corporate globalisation and develop alternative planetary systems that would justly co-accommodate all living beings. The political groundwork for such interdisciplinary collaboration is already there as both disciplines are interested in understanding the dialogic processes of border-crossings to reveal and forge points/moments of intervention and disruption in contemporary global formations. What they can offer each other is methodological and theoretical complexity and expansion. For instance, reception studies as borrowed in Feminist Translation Studies can help transnational feminist analyses highlight in detail the local and subjective interpretive processes of travelling knowledges and the appropriative roles of readers 
in their encounters with travelling texts (Ergun 2015, Amireh and Majaj 2000). In doing so, they help reveal the promises and risks of border-crossings. Or the dissident insights of anarchafeminism, for instance, on intellectual property, the translator's visibility (routinely celebrated in Feminist Translation Studies), authorship and transnational resistance can add innovative perspectives to the understanding and practice of feminist translation (Mainer 2017).

\section{GAPS IN THE FIELD: AN INVITATION FOR FUTURE INTERDISCIPLINARY WORK}

In addition to the aforementioned gaps that invite more intersectionally, spatially and transnationally informed scholarship on feminist translation, three other crucial gaps exist in the field of Feminist Translation Studies, which once again could be best addressed by interdisciplinary cooperations. First, the activist emphasis of the feminist praxis of translation seems to be lost in the process of the field's revitalisation over the last decade, as the centrality of feminist politics appears to be missing in the recently produced Feminist Translation Studies scholarship. Other than the newly published Feminist Translation Studies (Castro and Ergun 2017), there are currently no collections that fully focus on feminist translation and claim the political label of 'feminist' or 'activist' in their titles. The existing works generally focus on the dyads of 'gender \& translation' or 'women \& translation' without necessarily recognising the reactionary or transgressive operations of translation in feminist activisms and movements. Hence, the political role of translation in the trans/formation of local and transnational feminisms, among other things, requires more epistemic and analytical recognition. 
Second, the existing Feminist Translation Studies scholarship fails to reflect the recent crosscultural rise of attention given to feminist translation, particularly outside the EuroAmerican context and in the (post)colonial contexts within Europe (e.g. Catalan, Galician, Kurdish, etc.), or the emerging geographical diversity within the field (Devika 2008 on India, Mwangi 2009 on Tanzania, Yu 2015 on China). This gap not only perpetuates the false impression that feminist translation is exclusively on and of the west, but also discourages further knowledge production on and of non-western realities by keeping new Feminist Translation Studies theories and practices deterred or invisible. Two new collections interrupt this trend and invite scholarship on the geo/political functions and effects of feminist translation outside the context of the west: Translating Women: Different Voices and New Horizons edited by Farzaneh Farahzad and Luise von Flotow (2017) and Olga Castro and Emek Ergun's abovementioned collection (2017). These volumes highlight feminist translation in cultural/linguistic contexts as diverse as China, Cuba, India, Iran, Iraq, Japan, Turkey, Saudi Arabia, Mexico and Morocco. However, both of them are still in English and the gap in regard to Feminist Translation Studies scholarship produced in non-hegemonic languages remains an important one.

Third, a limited focus on literary translation is evident in Feminist Translation Studies, where the majority of the scholarship focuses on translations of literary works. This gap not only confines the theoretical, practical and political scope of feminist translation, but also wrongly implies that nonliterary translation (and interpreting) is neither creative nor political. In fact, much of transnational formations and border-crossings is not just textual (taking place in scripted platforms), as implied by the current Feminist Translation Studies scholarship, but also embodied and verbal, taking place in dialogues among differently situated bodies, subjectivities, languages/accents, voices, texts and discourses. This gap requires more research on how both 
nonliterary written texts/discourses as well as oral narratives/discourses and situated bodies/subjectivities/voices migrate and interact with one another across borders and contribute to the production of feminist knowledge and activism. There are already some studies exploring feminist strategies for translating audio-visual materials (De Marco 2012), advertisements (Corrius, De Marco and Espasa 2016), specialised texts (Bengoechea 2013) and scientific discourse (Sanchez 2007), as well as examining challenges for interpreters working in gender violence cases (Toledano and del Pozo 2015). We hope that these few works will inspire more studies on the use of feminist translation strategies in different genres and communicative venues.

All the gaps discussed above can be best addressed with interdisciplinary conversations and collaborations, which, we believe, hold the key to the future growth of Feminist Translation Studies - namely, a development beyond literature, a geopolitical expansion and an interdisciplinary growth. If the geopolitical, theoretical and methodological scope of Feminist Translation Studies is expanded, it will then become more intersectional, transnational and overtly political, moving beyond the disciplinary boundaries of Translation Studies. Other than producing scholarship, one important venue to achieve this inter/disciplinary expansion is to change the way we design and teach feminism and translation in university curricula - both within the translation classroom (see for example Susam-Sarajeva 2005; De Marco and Toto forthcoming 2018) and beyond Translation Studies, namely the curricula of courses on transnational feminisms, globalisation, international relations, comparative literature, social movements, history, sociolinguistics and intercultural communication (see Ergun and Castro 2017 for pedagogical strategies on how to incorporate Feminist Translation Studies in courses outside Translation Studies). Pedagogical intervention is a key strategy to increase collective 
literacy on the geo/politics of translation, which in the long run would not only help increase the scope of our knowledge on border-crossings, but also, more importantly, help us engage in more ethical translational encounters with one another - encounters that do not otherise, assimilate or fetishise our differences, but rather bring us eye-to-eye and connect us across those differences without pursuing oneness or sameness.

\section{RELATED TOPICS}

translation and globalisation, translation and international justice, translation and censorship, translation and activism, translation and the postcolonial, the politics of literary translation

\section{WORKS CITED}

Abou Rached, R. (2017) 'Feminist Paratranslation as Literary Activism: Iraqi Writer-Activist Haifa Zangana in the Post-2003 US', in O. Castro and E. Ergun (eds.) Feminist Translation Studies, NY: Routledge, 195-207.

Agorni, M. (2005) A Marginal(ized) Perspective on Translation History: Women and Translation in the Eighteenth Century', Meta 50(3): 817-830.

Alvarez, S. E., C. de L. Costa, V. Feliu, R. J. Hester, N. Klahn and M. Thayer (eds.) (2014)

Translocalities/Translocalidades, Durham: Duke UP.

Amireh, A. and L. Suhair Majaj (eds.) (2000) Going Global: The Transnational Reception of Third World Women Writers. NY: Garland.

An Inclusive Language Lectionary (1983) Philadelphia: Westminster Press. 
Appadurai, Arjun (1996) Modernity at Large, Minneapolis: University of Minnesota Press.

Arrojo, R. (1995) 'Feminist, 'Orgasmic' Theories of Translation and Their Contradictions', Tradterm 2: 67-75.

Arrojo, R. (1994) 'Fidelity and the Gendered Translation', TTR 7(2): 147-163.

Baer, B. J. and K. Kaindl (eds.) (forthcoming 2018) Queering Translation, Translating the Queer, NY: Routledge.

Basilio, E. (2017) 'Donne è Bello and the Role of Translation in the Migration of 'Consciousness-Raising' from the US to Italy', in O. Castro and E. Ergun (eds.) Feminist Translation Studies, NY: Routledge, 167-181.

Bassnett, S. and A. Lefevere (eds.) (1990) Translation, History and Culture, NY: Pinter.

Baxter, R. N. (2005) 'On the Need for Non-Sexist Language in Translation'. Language, Society and Culture 15. Available online: http://www.aaref.com.au/attachment.aspx?id=2159 [last access 31 January 2017].

Bengoechea, M. (2013) 'Feminist Translation? No Way! Spanish Specialised Translators' Disinterest in Feminist Translation', Women's Studies International Forum 42: 94-103.

Braun, F. (1997) 'Making Men out of People: The MAN Principle in Translating Genderless Forms', in H. Kotthoff and R. Wodak (eds.) Communicating Gender in Context, Amsterdam: Benjamins, 3-30.

Castro, O. (2013a) 'Introduction: Gender, Language and Translation at the Crossroads of Disciplines', Gender and Language 7(1): 5-12.

Castro, O. (2013b) 'Talking at Cross-Purposes? The Missing Link Between Feminist Linguistics and Translation Studies', Gender and Language 7(1): 31-58. 
Castro, O. (2010) 'Non-Sexist Translation and/in Social Change', in J. Boéri and C. Maier (eds.) Compromiso social y traducción/Interpretación: Translation/Interpreting and Social Activism, Granada: ECOS, 106-120.

Castro, O. and E. Ergun (eds.) (2017) Feminist Translation Studies, NY: Routledge.

Chamberlain, L. (1988) 'Gender and the Metaphorics of Translation', Signs, 13(3): 454-472.

Clockroot.com (2011). 'Women \& Publishing, Women \& Translation, Publishing Women in Translation', 6 February. Available $\quad$ online: http://clockrootbooks.com/wordpress/2011/02/women-publishing-women-translationpublishing-women-in-translation/ [last accessed 31 January 2017].

Combahee River Collective (2015) 'A Black Feminist Statement', in C. Moraga and G. Anzaldúa, This Bridge Called My Back, 4th edition, NY: SUNY Press, 210-218.

Corrius, M., M. De Marco and E. Espasa (2016) 'Situated Learning and Situated Knowledge: Gender and Translating Audiovisual Adverts', The Interpreter and Translator Trainer, 10(1): 59-75.

Costa, C. de L. (2006) 'Lost (ând Found?) in Translation: Feminisms in Hemispheric Dialogue', Latino Studies 4: 62-78.

Costa, C. de L. and S. E. Alvarez (2014) 'Dislocating the Sign: Toward a Translocal Feminist Politics of Translation', Signs 39(3): 557-563.

Crenshaw, K. (1989) 'Demarginalizing the Intersection of Race and Sex', The University of Chicago Legal Forum 140: 139-167.

Davis, K. (2007) The Making of Our Bodies, Ourselves: How Feminism Travels Across Borders. Durham: Duke UP.

De Marco, M. (2016) 'The 'Engendering' Approach in AVT', Target 28(2): 314-325. 
De Marco, M. (2012) Audiovisual Translation through a Gender Lens, Amsterdam: Rodopi.

De Marco, M. and P. Toto, (eds.) (forthcoming 2018) Gender Approaches in the Translation Classroom, Basingstoke: Palgrave.

Delisle, Jean (dir.) (2002) Portraits de traductrices. Ottawa: Artois Presses Université.

Delisle, Jean (dir.) (2000) Portraits de traducteurs. Ottawa: Artois Presses Université.

Dépêche, M. (2002) 'As traduções subversivas feministas ontem e hoje', Lầbrys, Estudos Feministas 1-2. Available online: http://www.ebah.com.br/content/ABAAABnGUAB/astraducoes-subversivas-feministas-ontem-hoje [last access 31 January 2017].

Devika, J. (2008) 'Being 'In-Translation' in a Post-Colony: Translating Feminism in Kerala State, India', Translation Studies 2: 182-196.

Epstein, B. J. and R. Gillett (eds.) (2017) Queer in Translation, NY: Routledge.

Ergun, E. (2017) 'Translational Beginnings and Origin/izing Stories: (Re)Writing the History of the Contemporary Feminist Movement in Turkey', in F. Farahzad and L. von Flotow, Translating Women, NY: Routledge, 41-55.

Ergun, E. (2015) 'Doing Feminist Translation as Local and Transnational Activism: The Turkish Translation of Virgin The Untouched History and Its Reception', PhD diss., University of Maryland, Baltimore County, US.

Ergun, E. (2013a) 'Feminist Translation and Feminist Sociolinguistics in Dialogue: A Multilayered Analysis of Linguistic Gender Constructions in and across English and Turkish', Gender and Language 7/1: 9-29.

Ergun, E. (2013b) 'Reconfiguring Translation as Intellectual Activism: The Turkish Feminist Remaking of Virgin: The Untouched History', Trans/Scripts 3: 264-289. 
Ergun, E. and O. Castro (2017) 'Pedagogies of Feminist Translation: Rethinking Difference and Commonality Across Borders', in O. Castro and E. Ergun (eds.) Feminist Translation Studies, NY: Routledge, 93-108.

Farahzad, F. (2017) 'Women Translators in Contemporary Iran', in L. von Flotow and F. Farahzad (eds.) Translating Women, NY: Routledge, 3-15.

Ferguson, M. (ed.) (1985) First Feminists: British Women Writers 1578-1799. Bloomington: Indiana UP.

Flotow, L. von (2009) 'Contested Gender in Translation: Intersectionality and Metramorphics', Palimpsestes 22: 249-256.

Flotow, L. von (2000) 'Women, Bibles, Ideologies', TTR 13(1): 9-20.

Flotow, L. von (1999) 'Genders and the Translated Text,, Textus 12: 275-288.

Flotow, L. von (1997) Translation and Gender, Manchester: St. Jerome.

Flotow, L. von (1991) 'Feminist Translation. Contexts, Practices and Theories', TTR 4(2): 69-84.

Flotow, L. von and J. W. Scott. 2016. 'Gender Studies and Translation Studies: "Entre Braguette" - Connecting the Transdisciplines', in Y. Gambier and L. van Doorslaer (eds.) Border Crossings: Translation Studies and Other Disciplines, Amsterdam: Benjamins, 349-374.

Guillaumin, C. (1995) Racism, Sexism, Power and Ideology. London \& NY: Routledge.

Godard, B. (1990) 'Theorizing Feminist Discourse/Translation', in S. Bassnett and A. Lefevere (eds.) Translation, History, Culture. NY: Pinter, 87-96.

Hassen, R. (2011). 'English Translation of the Quran by Women', MonTI 3: 211-230.

Haugerud, J. (1977) The Word for Us, Gospels of John and Mark, Epistles to the Romans and the Galatians. Seattle: Coalition of Women in Religion. 
Henitiuk, V. (1999) Translating Woman: Reading the Female through the Male, Meta 44(3): 469-484.

Kaplan, C. (1994) The Politics of Location as Transnational Feminist Critical Practice, in I. Grewal and C. Kaplan (eds.) Scattered Hegemonies, Minnesota: University of Minnesota Press, 137-152.

Larkosh, C. (ed.) (2011) Re-Engendering Translation. Manchester: St Jerome.

Lefevere, A. (1992) History Translation Culture. Oxford: Routledge.

Leonardi, V. (2007) Gender and Ideology in Translation: Do Women and Men Translate Differently? A Contrastive Analysis from Italian into English. Bern: Peter Lang.

Levine, S. J. (1983) 'Translation as (Sub)version: On Translating Infante's Inferno', Substance 42: 85-94.

Levine, S. J. (1991) The Subversive Scribe. Saint Paul: Graywolf Press.

Liu, L. H. (1995) Translingual Practice: Literature, National Culture, and Translated Modernity - China 1900-1937. Stanford: Stanford UP.

Lotbinière-Harwood, S. de (1988) 'Re-Writing in the Feminine', in D. Homel and S. Simon (eds.) Mapping Literature: The Art and Politics of Translation, Montreal: Véhicule Press.

Lotbinière-Harwood, S. de (1991) Re-Belle et Infidèle/The Body Bilingual, Toronto: Women's Press.

Maier, C.(1985) ‘A Woman in Translation, Reflecting', Translation Review 17: 4-8.

Maier, C. (1996) 'Recovering, Re-covering, and the Translation of Work by Rosa Chacel and María Zambrano', in A. Sobejano-Moran (ed.) Feminism in Multi-cultural Literature, Lewiston: Edwin Mellen Press, 207-223. 
Maier, C. (1998) 'Issues in the Practice of Translating Women's Fiction', Bulletin of Hispanic Studies 75(1): 95-108.

Maier, C. and F. Massardier-Kenney (1996) 'Gender in/And Translation', in M. Gaddis Rose (ed.) Translation Horizons, NY: SUNY Press, 225-242.

Mainer, S. (2017) 'Rote Zora in Spanish: Anarcha-Feminist Activism in Translation', in O. Castro and E. Ergun (eds.) Feminist Translation Studies, NY: Routledge: 181-194.

Martín Ruano, M. R. (2005) ‘Gender(ing) Theory: Rethinking the Targets of Translation Studies in Parallel with Recent Developments in Feminism', in J. Santaemilia (ed.) Gender, Sex and Translation. Manchester: St. Jerome, 27-37.

Massardier-Kenney, F. (1997) 'Towards a Redefinition of Feminist Translation Practice', The Translator 3(1): 55-69.

Min, D. (2014) ‘Toward an Alternative Traveling Theory’, Signs 39(3): 584-592.

Moi, T. (2010) 'The Adulteress Wife: Review on The Second Sex', London Review of Books 32(3): 3-6.

Moi, T. (2004) 'While We Wait: Notes on the English Translation of The Second Sex', in E. Grosholz (ed.) The Legacy of Simone de Beauvoir, Oxford: Oxford UP, 37-68.

Möser, C. (2017) 'Gender Traveling across France, Germany and the US', in O. Castro and E. Ergun (èds.) Feminist Translation Studies, NY: Routledge, 181-194.

Mwangi, E. '(2009) 'Amandina Lihamba's Gendered Adaptation of Sembene Ousmane's The Money-Order', Research in African Literatures 40(3): 149-173.

Nagar, R. (2014) Muddying the Waters: Coauthoring Feminisms Across Scholarship and Activism. Urbana: University of Illinois Press. 
Reimóndez, M. (2009) 'The Curious Incident of Feminist Translation in Galicia: Courtcases, Lies and Gendern@tions', Galicia 21, Issue A: 68-89.

Resnick, M. and I. de Courtivron (eds.) (1984) Women Writers in Translation: An Annotated Bibliography 1945-1982. NY: Garland.

Rich, A. (1986) Blood, Bread, and Poetry: Selected Prose 1979-1985. NY: W. Norton \& Company.

Said, E. W. (1994) 'Traveling Theory Reconsidered', in R. M. Polhemus and R. B. Henkle (eds.), Critical Reconstructions, Stanford: Stanford UP, 251-265.

Said, E. (1983) The World, the Text, and the Critic, Cambridge: Harvard UP.

Sanchez, L. (2017) 'Translation and the Circuits of Globalisation: In Search of More Fruitful Feminist Dialogues in Contemporary Spain', in O. Castro and E. Ergun (eds.) Feminist Translation Studies, NY: Routledge, 56-69.

Sanchez, L. (2007) 'The Truth about Sexual Difference. Scientific Discourse and Cultural Transfer', The Translator 13(2): 171-194.

Sandoval, C. (2000) Methodology of the Oppressed, Minneapolis: University of Minnesota Press.

Shaw, S. (1993) A Religious History of Julia Evelina Smith's 1876 Translation of the Holy Bible. San Francisco: Mellen Research.

Shlesinger, M., M. Koppel, N. Ordam and B. Malkiel (2010) 'Markers of Translation Gender: Do They Really Matter?', in I. M. Mees, F. Alves and S. Göpferich (eds.) Methodology, Technology and Innovation in Translation Process Research, Copenhagen: Samfundslitteratur: 183-198.

Simon, S. (1996) Gender in Translation, NY: Routledge. 
Simons, M.A. (2001) Beauvoir and The Second Sex, Maryland: Rowman and Littlefield.

Spivak, G. C. (1993) 'The Politics of Translation', in G. C. Spivak, Outside in the Teaching Machine, NY: Routledge: 179-200.

Susam-Sarajeva, S. (2005) 'A Course on 'Gender and Translation' As An Indicator of Certain Gaps in the Research of the Topic', in J. Santaemilia (ed.) Gender, Sex and Transtation, Manchester: St. Jerome, 161-176.

Thayer, M. (2010) Making Transnational Feminism: Rural Women, NGO Activists, and Northern Donors in Brazil, NY: Routledge.

Toledano, C., M. I. Abril, M. del Pozo and L. Aguilera (2015) Towards the Specialization of Public Service Interpreters in the Area of Gender-based Violence', MonTi 5(special issue 2): $139-160$.

Tyulenev, S. (2011) 'Women-Translators in Russia', MonTI 1: 75-105.

Venuti, L. (2000) The Translation Studies Reader, NY: Routledge.

Voldeng, E. (1985) 'The Elusive Source Text’, Canadian Literature 105: 138-139.

Wolf, M. (2005) 'The Creation of A Room of One's Own. Feminist Translators as Mediators Between Cultures and Genders', in J. Santaemilia (ed.) Gender, Sex and Translation, Manchester: St. Jerome, 15-25.

Yu, Z. (2015) Translating Feminism in China. NY: Routledge.

\section{FURTHER READINGS}

a) Castro, O. and E. Ergun (2017) Feminist Translation Studies. Local and Transnational Perspectives, NY: Routledge. 
This recent collection is composed of 16 essays that explore translation as a form of local and transnational feminist activism from different interdisciplinary perspectives, while at the same time seeking to geopolitically intervene in the Anglo-Eurocentric scope of the field. It includes a round-table discussion with leading scholars on the feminist politics of translation.

b) Flotow, L. von and F. Farahzad (2017) Translating Women. Different Vôices and New Horizons, NY: Routledge. [A sequel of the first part: Flotow, L. von (2011) Translating Women, Ottawa: U. Ottawa Press.]

Written in response to critiques of Luise von Flotow's earlier volume, Translating Women (2011) for having a Western-centric scope, this recent collection brings together 13 essays focusing on women translators, women authors in translation, the translational travels of western feminisms to other cultures, and various feminist translation projects.

c) Alvarez, S. E., C. de L. Costa, V. Feliu, R. J. Hester, N. Klahn and M. Thayer (eds.) (2014) Translocalities/Translocalidades. Feminist Politics of Translation in the Latin/A Américas, Durham: DukeUP.

This collection is composed of 20 chapters exploring the roles of translation and translators in enabling hemispheric feminist dialogues within and across the geopolitical contexts of Latin American, Caribbean and US-based Latina feminisms.

d) Simon, S. (1996) Gender in Translation. Cultural Identity and the Politics of Transmission, NY: Routledge. 
This monograph provides an in-depth discussion of the need for taking gendered perspective about translation theory, highlighting the importance of the ethical position when approaching both feminist and 'ideologicall unfriendly' texts. Simon also revisits the history of feminist intellectuals in different activities of intercultural transmission of knowledge, including translation.

e) Yu, Z. (2015) Translating Feminism in China. Gender, Sexuality and Censorship, NY: Routledge.

This monograph offers a valuable contribution to the study of feminist translation within and outside China. Yu presents a thorough analysis of the Chinese translations of milestone feminist texts such as The Second Sex and The Vagina Monologues, exploring to what extent censorship might have affected these translations.

\section{BIOGRAPHICAL NOTE}

Olga Castro is Lecturer in Translation Studies at Aston University, Birmingham, UK. Her main area of research is feminist translation studies. She is interested in exploring the social and political role of translation in the construction of gender and cultural/national identities in a transnational world, with a particular focus on the non-hegemonic cultural/linguistic contexts of Spain.

Emek Ergun is an activist-translator and Assistant Professor of Women's and Gender Studies and Global Studies at the University of North Carolina at Charlotte, US. Her research explores 
creative operations of translation in connecting feminist activists, discourses and movements across contentious geopolitical borders, particularly between Turkey and the US. 